\title{
THE MODEL OF PROJECTS CREATION OF THE FIRE EXTINGUISHING SYSTEMS IN COMMUNITY TERRITORIES
}

\author{
Anatoliy Tryhubaํ, Roman Ratushny², Inna Tryhuba³, Nazar Koval², \\ Igor Androshchuk ${ }^{4}$
} ${ }^{1}$ Faculty of Mechanics and Power Engineering, Lviv National Agrarian University, str. Vladimir the Great, 1,
Dublyany, Zhovkva district, Lviv region, 80381, Ukraine
${ }^{2}$ Institute of Civil Defence, Lviv State University of Life Safety, str. Kleparovska, 35, Lviv, 79007, Ukraine
${ }^{3}$ Faculty of Agrotechnology and Ecology, Lviv National Agrarian University, str. Vladimir the Great, 1, Dublyany,
Zhovkva district, Lviv region, 80381, Ukraine
${ }^{4}$ Faculty of Ecology, Tourism and Electrical Engineering, Lutsk National Technical University, str. Lvivska, 75,
Lutsk, 43018, Ukraine

Link to this article: https://doi.org/10.11118/actaun202068020419

Received: 28. 9. 2019, Accepted: 5. 2. 2020

To cite this article: TRYHUBA ANATOLIY, RATUSHNY ROMAN, TRYHUBA INNA, KOVAL NAZAR, ANDROSHCHUK IGOR. 2020. The Model of Projects Creation of the Fire Extinguishing Systems in Community Territories. Acta Universitatis Agriculturae et Silviculturae Mendelianae Brunensis, 68(2): 419-431.

\begin{abstract}
The state of the united Ukrainian territorial communities fire extinguishing systems and trends in their development have been analyzed. The the united territorial communities development expediency scientific-methodical bases and service model of fire extinguishing systems projects has been proved. Developed scientific-methodical bases and service model take into account features of changing project environment of the projects in relation to the united territorial community fire extinguishing systems projects model, based on the prediction variability in reference to the fires number and type, take into account the roads condition and provide fire extinguishing systems in the desired state. Based on the united territorial community fire extinguishing systems algorithm service model project computer program has been developed. The proposed computer program provided an opportunity to substantiate trends in organizational-technological parameters values of the fire extinguishing systems projects regarding combined territorial communities. Regularities of changes in reference to organizational and technological indicators of the projects value concerning the fire extinguishing systems has been developed for conditions of Zhovtanets united territorial community.
\end{abstract}

Keywords: service model, project, fire extinguishing system, territorial community, configuration

\section{INTRODUCTION}

Nowadays, the territorial Fire Fighting Systems (FFS), which are components of State Emergency Service (SES) of Ukraine, operates inefficiently, which leads to the loss of life and significant material damage due to fires (Tryguba, 2018). This is particularly evident in the territory of rural administrative districts, which are the most vulnerable to fires. A number of measures are being implemented in the state to reform the SNS. In particular, the reform has developed a strategy for the SES, regional programs are being implemented on the territory of rural administrative districts range of local projects united territorial communities (UTC). They receive funding from both the public and the local budgets of individual regions and UTC. However, they do not create the maximum value for the residents of the UTC because they did not involve development of 


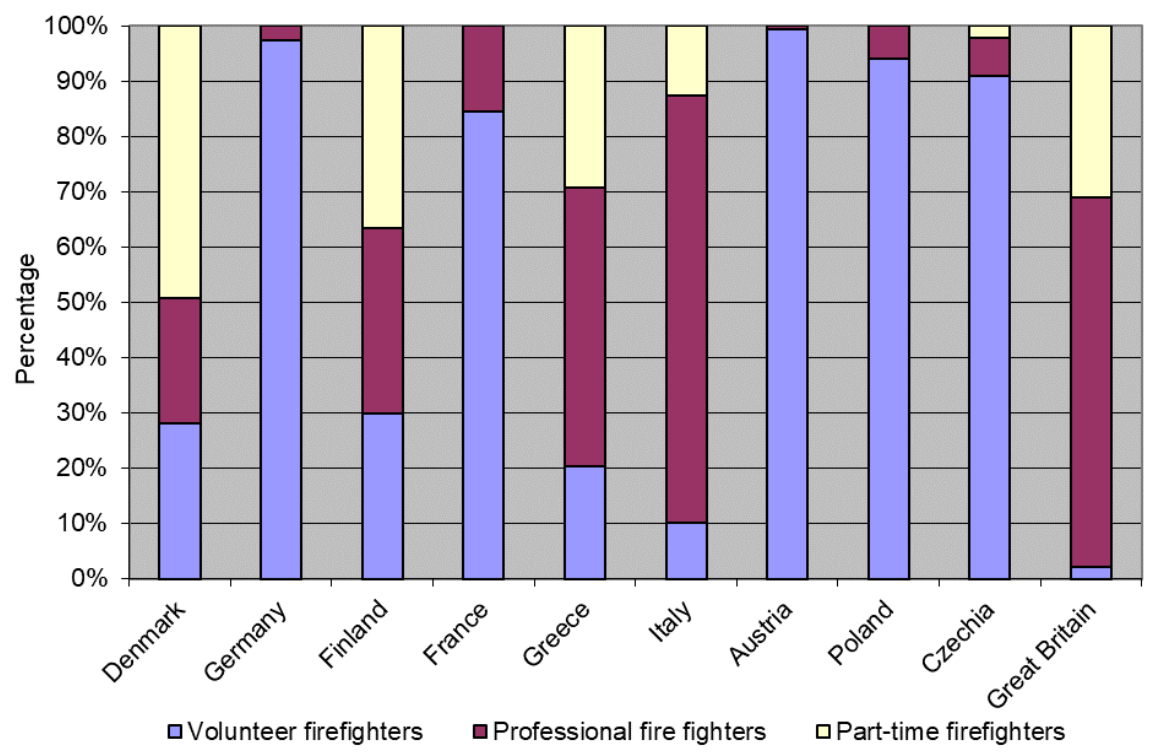

1: Structure of fire extinguishing systems in European countries

the conceptual project plans for the fire fighting systems of the united territorial communities (FFS UTC) development, which is based on the project management methodology (Sabolovič, 2011; Kopečková et al., 2016). Reformation of FFS UTC is possible only with the system implementation of the FFS UTC and ensuring good governance. This requires System Value Principles, models, methods and tools of project management of FFS UTC development (Tryguba, 2018).

To determine the maximum value from developing FFS for individual UTC methods and models should be used, which will take into account both the specific characteristics of their changing project environment (presence of settlements, the number of inhabitants and the number of potentially-dangerous objects, their geographical locations, the road network), and a finite set of possible scenarios for their implementation. This will ensure appropriate definition of projected values, which underpin the development of effective conceptual plans of those projects (Kopečková et al., 2016; Machado Tavares et al., 2007).

It is known (Tryhuba et al., 2018) that the vast majority of rural settlements are unprotected from fires. In particular, the duration of fire brigades arrival to the fire scene in rural areas is significantly higher than the allowable value (20 min). In the overwhelming majority it is due to the territorial location of the nearest Emergency Fire \& Rescue Unit to rural settlements (the average value varies approximately $30-40 \mathrm{~km}$ ) and the roads in rural areas of the state condition. Based on the analysis of a number of works (Trush, 2009; Kovalchuk, 2015; Baigent, 2001; Clancy et al., 2004; Ferreira et al., 2016) on the the fire extinguishing systems in different countries functioning it can be argued that they are mainly formed by local authorities and the majority prevail volunteer fire departments. They involve the engagement of voluntary and part-time firefighters (Fig. 1).

Foreign experience proclaims that voluntary fire brigades are created in all European countries, which ensure the integration of efforts and resources of certain territories local residents for the fires' prevention and elimination.

The the structure of the fire extinguishing system in European countries analysis (Fig. 1) proclaims that the number of voluntary fire brigades are dominated by the professional firefighters presence (except Great Britain). This makes it possible to ensure the fire fighting systems in these countries effectiveness and the fire protection of the territories and population living on them. In addition, volunteering and will in Europe are the responsibility of every citizen of the state.

In order to create voluntary fire brigades in each of the above-mentioned European countries, appropriate conditions have been created. In particular, in these countries tribute stimulation of firefighters and the creation of conditions for their social protection at the legislative level are provided.

The question substantiation of the configuration of the FES is devoted to a number of scientific works dealing with different regions (Gwynne et al., 2003; Marrion, 2016; Mclennan et al., 2008; Lovreglio et al., 2015). An analysis of these works testify that the existing methods and models of the justification of the FES configuration are characterized by many drawbacks. In particular, they do not take into detail environment mutable design, which is specific to each of the associated local authorities of individual administrative territories of the state. In addition, they do not antedate the possibility of implementing the Project of development extinguishing systems associated local authorities (PDSF) in different 
scenarios, which greatly affects the value on their product.

Adequate prediction of a changing design environment and the use of the PDSF product is possible only on the basis of its modeling, which requires specific research and the development of an appropriate service model (Máchal, 2009; Ratushnyi et al., 2019; Tryhuba et al., 2019; Tryhuba et al., 2018). Due to failure to take into account the specific project environment of the PDSF for each UTC, as well as without forecasting the value of their product, it is impossible to adequately substantiate the configuration of the ES in the desired state.

Scientific papers (Xin et al., 2013; Hulida et al., 2019), which partly take into account the changing characteristics of the project environment and the prediction of the number of fires in human settlements. However, they mostly relate to municipal FFS, which do not adequately reflect the possibility of implementing PDSF under different scenarios and modeling the FFS in the desired state, which does not provide the opportunity to adequately substantiate their configuration.

To objectively substantie conditions of fire protection of rural areas. In addition, they do not take into account the FFS configuration for individual UTC, it is necessary to develop a scientific methodological basis and a service model of the PDSF, which will take into account the identified features of a changing design environment, provide prediction of the number of fires, and also provide simulation of FFS modeling in the desired condition.

The purpose of the article is to justify the scientific and methodological principles and service model of PDSF, which will provide determination of predicted index of their values, which underlie the development of effective conceptual plans of these projects.

To achieve this goal you should solve the following tasks

- to propose scientific and methodological principles of justification of the configuration of the UTC in the desired condition;

- to develop a service model of PDSF;
- to accomplish the modeling of the FFS UTC in the desired condition and to identify the main organizational and technological indicators of the value of PDSF in the desired condition.

\section{MATERIALS AND METHODS}

The justification of the configuration of the firefighting system of the united territorial communities in the desired state is based on the conceptual and simulation models and ensures the determination of the effective type of the fire depot and its optimal territorial location in the community. Unlike the existing ones, it provides for the use of a comprehensive criterion of fire insecurity of populated areas of the united territorial communities, taking into account the changing configuration of the project environment (the number of inhabitants in populated areas, the availability of fire-hazardous facilities and the characteristics of the road network, etc.). The criterion for determining the territorial location of fire stations in the territory of the united territorial communities is the level of fire insecurity $\left(L_{f i}^{m}\right)$ of its j settlements, according to the expression:

$L_{f i}^{m}=n_{n j}^{m} \times t_{i, j}^{m}$,

where $L_{f i j}^{m}$ - is the level of the fire insecurity of a populated area that is part of joint territorial communities, fire-minutes; $n_{n j}^{m}$ - number of fires in the village, units; $t_{i, j}^{m}$ - the duration of the arrival of fire and rescue units from the location of the fire station in another populated area of the united territorial communities to the site of burning of the settlement (duration of free burning of objects), min.

The territory of a separate UTC can be represented in the form of a graph (Fig. 2).

In the united territorial communities the population $\left(N_{p o}^{m}\right)$ is limited, which is distributed on the territory of its junctions:

$N_{p o}^{m}=\left\{n_{p o_{j}}\right\}, j=1, n$,

where $N_{p o}^{m}$ - the number of people living in the territory of the united territorial communities,
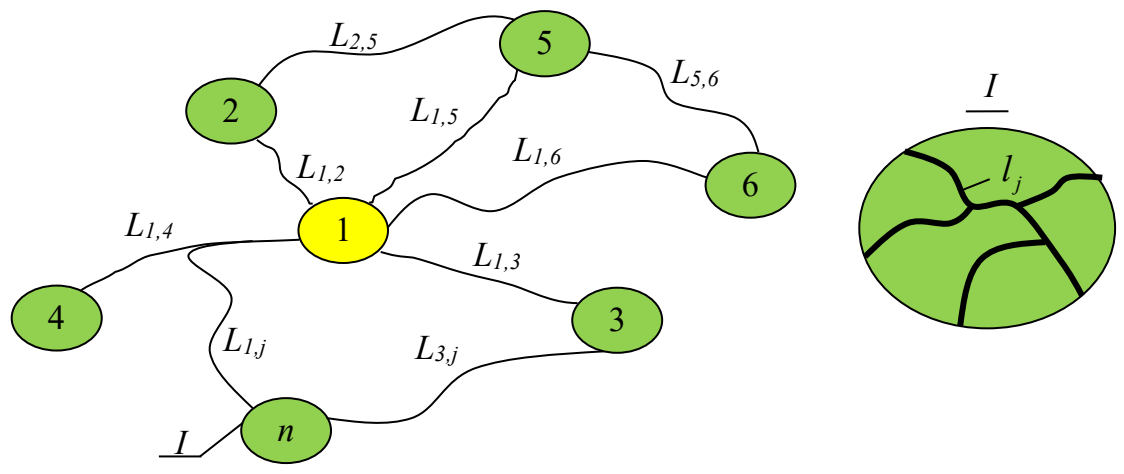

2: A graph of the location of settlements in the territory of the combined territorial communities: $1,2, \ldots, n$-the number of the settlement; $L_{1}$, -distance between $1^{\text {st }}$ and $2^{\text {nd }}$ settlements; $l_{j}^{m}$ - the distance of the longest branch of the inner network of the city's settlement 
persons; $n_{p o_{i}}$ - the number of people residing on the territory of a community of joint territorial communities, individuals; $n$ - number of settlements in the territory of the united territorial communities, units.

Having quantitative values of the characteristics of objects in the configuration of the project environment, the annual number of fires $\left(n_{n j}^{m}\right)$ in the populated area, which depends on the population $\left(n_{p o j}\right)$ in it:

$n_{n j}^{m}=f\left(n_{p o j}\right)$,

where $n_{n j}^{m}$ - the annual number of fires in a community of joint territorial communities, units; $n_{p o j}$ - the population in a community of joint territorial communities, people.

The territory of a single unified territorial community is described by the model of the territorial location of settlements with a network of roads, fed in the form of a matrix of shortest distances along general roads between its individual settlements:

$M_{L}^{m}=\left\{L_{i, j}^{m}\right\}, i=1, n, j=1, n$,

where $M_{L}^{m}$ - is the matrix of the shortest distances along general roads between separate settlements of the united territorial communities; $L_{i j}^{m}$ - distance on the general-purpose road between one and the second settlement of the united territorial communities; $n$ - number of settlements in the united territorial communities.

The state of the roads of a single unified territorial community is described by a model, fed in the form of a matrix of road condition coefficients:

$M_{k}^{m}=\left\{k_{i, j}^{m}\right\}, i=1, n, j=1, n$,

where $M_{k}^{m}$ - is the matrix of road state coefficients between individual communities of the joint territorial communities; $k_{i j}^{m}$ - the coefficient of the state of roads between one and the other settlements of the united territorial communities; $n$ - number of settlements in the united territorial communities.

Having models of the territorial location of settlements with a network of roads of separate unified territorial communities (4) and the state of roads on its territory (5) form the matrix of the duration of the arrival of fire-fighting units to the fires:

$M_{t}^{m}=\left\{t_{i, j}^{m}\right\}, i=1, n, j=1, n$,

where $M_{t}^{m}$ - the matrix of the duration of the arrival of fire and rescue units to the fires of joint territorial communities; $t_{i j}^{m}$ - the duration of the arrival of fire and rescue units from the place of dislocation in the settlement to the burning site of the populated area of the united territorial communities; $n$-number of settlements in the territory of the united territorial communities.
Based on the values of the projected number of fires in $\mathrm{j}$ settlements $\left(n_{n j}^{m}\right)$ (3) and using the model of the duration of the arrival of firefighters to the fires in the territory of the united territorial communities (6), perform the appropriate and form a matrix of fire insecurity levels $\left(L_{f i j}^{m}\right)$ of its settlements with different options for the location of fire stations in i-X settlements:

$M_{L}^{m}=\left\{L_{f j}^{m}\right\}, i=1, n, j=1, n$,

where $M_{L}^{m}$ - is the matrix of levels of fire insecurity of populated areas for the location of fire depots in populated areas in the territory of joint territorial communities, fire-min; $L_{f i j}^{m}$ - level of fire insecurity of the settlement for the location of the fire station in the populated area in the territory of the united territorial communities, fire-min.

For each of organizational development options of the fire extinguishing system (FES) by association of local communities (UTC) ( $k$-type of fire depot) determine the quantitative significance of the levels of fire insecurity $L_{f i}^{m k} j$-x of settlements for the location of fire depots in the $i$-x settlements in the territory $m$ of fire extinguishing system (FES) by using the formula (1). On the using basis data of the matrix (7) determine the total level of the fire insecurity of settlements $\left(L_{f i}^{m k}\right)$ regarding location $k$-x types of fire depots in each of the settlements $i$-x on the territory $\mathrm{T}$ which includes association of local communities:

$L_{f i}^{m k}=\sum_{j=1}^{n} L_{f i j}^{m k}$,

where $L_{f i}^{m k}$ - the total level of fire insecurity of settlements for the location $k$-types of fire depots in $i$ settlements $\mathrm{T}$ association of local communities, fire-min; $L_{f i j}^{m k}$ - the level of fire insecurity of the $j$ settlements for the location $k$-types of fire depots in $i$ settlements $m$ association of local communities, fire-min; $n$-the number of settlements on the territory of the association of local communities (UTC).

An effective configuration of the fire extinguishing system is considered to be like that $\left(K_{S 6}^{e f}\right)$ in the right state of $m$ association of local communities, which provides the minimum level of fire protection of its settlements:

$K_{S \sigma}^{e f}=f\left(L_{f i}^{m k}\right) \rightarrow \min$.

For the accelerated substantiation of the configuration of the fire extinguishing system (FES) of the association of local communities (UTC) in the right state we have developed a service model for the fire-fighting of the united territorial communities (PDSF). It provides simulation of project environment configurations (PFSF). The block-diagram of the algorithm (Fig. 3) and the computer program of the service model of firefighting of the combined territorial communities (PDSF) provide for the implementation of 23 steps. 
The algorithm of the service fire extinguishing model of the combined territorial communities (PDSF) is implemented in the following sequence:

1. To insert in the PC the characteristics of the objects of the design environment of the PDSF: the number of settlements $\left(n_{i}\right)$ on the territory of the UTC population $\left(n_{p o}\right)$ and objects of high fire hazard $\left(n_{0}\right)$ in each of them.

2. To insert in the memory of the PC the model of the content and time of execution of works in the PFSF. Create the required number of variables and their multitude. Reset the variables and their multitude to ensure the model is working correctly.

3. To generate rows of average lengths of information on the occurrence of a fire $\left(t_{i \mathrm{H}}\right)$, gathering of a team for the departure to the fire $\left(t_{3}\right)$ and the deployment of combat settlements $\left(t_{p}\right)$ :

$M_{t_{i H}}:=\left\{t_{i H^{k}}\right\}, k=\overline{1, n_{k}}$,

$M_{t_{3}}:=\left\{t_{t_{3} k}\right\}, k=\overline{1, n_{k}}$,

$M_{t_{p}}:=\left\{t_{t_{p} k}\right\}, k=\overline{1, n_{k}}$.

where $n_{k}$ - the number of organizational options for the development of FES UTC ( $k$-x types of fire depots), units.

4. To form multitude of speed of movement $\left(V_{i}\right)$ of fire and rescue units on roads, of $\varepsilon$-type in settlements and outside them, distances $\left(D_{i, j}\right)$ and types $\left(\varepsilon_{i, j}\right)$ of roads between separate settlements:

$M_{V_{i j}}:=\left\{V_{i j}\right\}, i=\overline{1, \varepsilon}, i=\overline{1, v}$

$M_{L_{i, j}}:=\left\{D_{i, j}\right\}, i=\overline{1, n}, j=\overline{1, n}$,

$M_{\varepsilon_{i, j}}:=\left\{\varepsilon_{i, j}\right\}, i=\overline{1, n}, j=\overline{1, n}$,

where $\varepsilon$ - is the road view; $v$ - type of restrictions on the speed of the VF; $n$ - the number of settlements in the territory of UTC.

5. Determine the coefficients $\left(k_{i, j}\right)$ of the state of roads between $i$ and $j$ settlements of the UTC and form their multitude:

$M_{k}:=\left\{k_{i, j}\right\}, i=\overline{1, n}, j=\overline{1, n}$,

where $n$ - number of settlements on the territory of the UTC.

6. To carry out the forecasting of the annual number of fires $\left(n_{n j}\right)$ in $\mathrm{j}$ settlements located on the territory of UTC. UTC $\left(\psi=1,2, \ldots, n_{i}\right)$.

7. Specify this variant $\left(C_{K}\right)$ the configuration of the FES UTC in the right one, selected from a plurality $\left\{C_{n_{k} n_{i}}\right\}$ of $\left(k=1,2, \ldots, n_{k}\right)$ and the territorial location of the fire depot in the $i$ locality of the

$C_{K} \in\left\{C_{n_{k} n_{i}}\right\}, k=\overline{1, n_{k}}, \psi=\overline{1, n_{i}}$,

Where $n_{k}$ - the number of organizational options for the development of FES UTC ( $k$ - types of fire depots), units; $n_{i}$ - number of settlements of the UTC in which the fire depot is located, units.

8. To determine the duration $\left(t_{i, j}\right)$ of arrival of the VF from the place of deployment of fire depots in i settlement to the combustion object of the j settlement and to form their multitude:

$M_{t}:=\left\{t_{i, j}\right\}, i=\overline{1, n}, j=\overline{1, n}$,

Where $n$-number of settlements on the territory of the UTC.

9. To detect fire insecurity levels $\left(L_{f j i}\right) j$-x of local populated are as due to alternative locations of fire station in the populated area and their array formations:

$M_{R}:=\left\{L_{f i j}\right\}, i=\overline{1, n}, j=\overline{1, n}$,

10. To determinethe total fire insecurity levels of populated areas $\left(L_{f}^{k}\right)$ due tospecified configuration alternative of local authorities fire extinguishing systems in the desired level (location of $k$ fire station type in $i$ local authority populated area):

$L_{f i}^{k}=\sum_{j=1}^{n} L_{f i j}^{k}$

Where $L_{f j}^{k}$ - fire insecurity level j populated area due to location of $k$ fire station type in $i$ local authority populated area, fire-min; $n$ - the number of populated areas on the territory of the local authority.

11. To check the availability of pending configuration alternatives of local authorities fire extinguishing systems in the desired level. In case of their availability go back to p. 8. In case of their non-availability - go to p. 13.

12. To form an array of values of total populated areas fire insecurity levels $\left(L_{f}^{k}\right)$ due to different configuration alternatives of local authorities fire extinguishing systems) in the desired level:

$M_{L_{f}^{k}}:=\left\{L_{f i}^{k}\right\}, i=\overline{1, n}, j=\overline{1, n_{k}}$.

13. To perform a ranking of values of total populated areas fire insecurity levels $\left(L_{f}^{k}\right)$, which are in the array $\left(M_{L_{f}^{k}}\right)$, in their ascending order:

$M_{L_{f i}^{m k}}:=\left\{L_{f 4}^{m 3}<L_{f 2}^{m 2}<\ldots<L_{f i}^{m k}\right\}$.

Where $L_{f i}^{m k}$ - total populated areas fire insecurity level due to location of $k$ fire station type in i populated area, fire-min. 


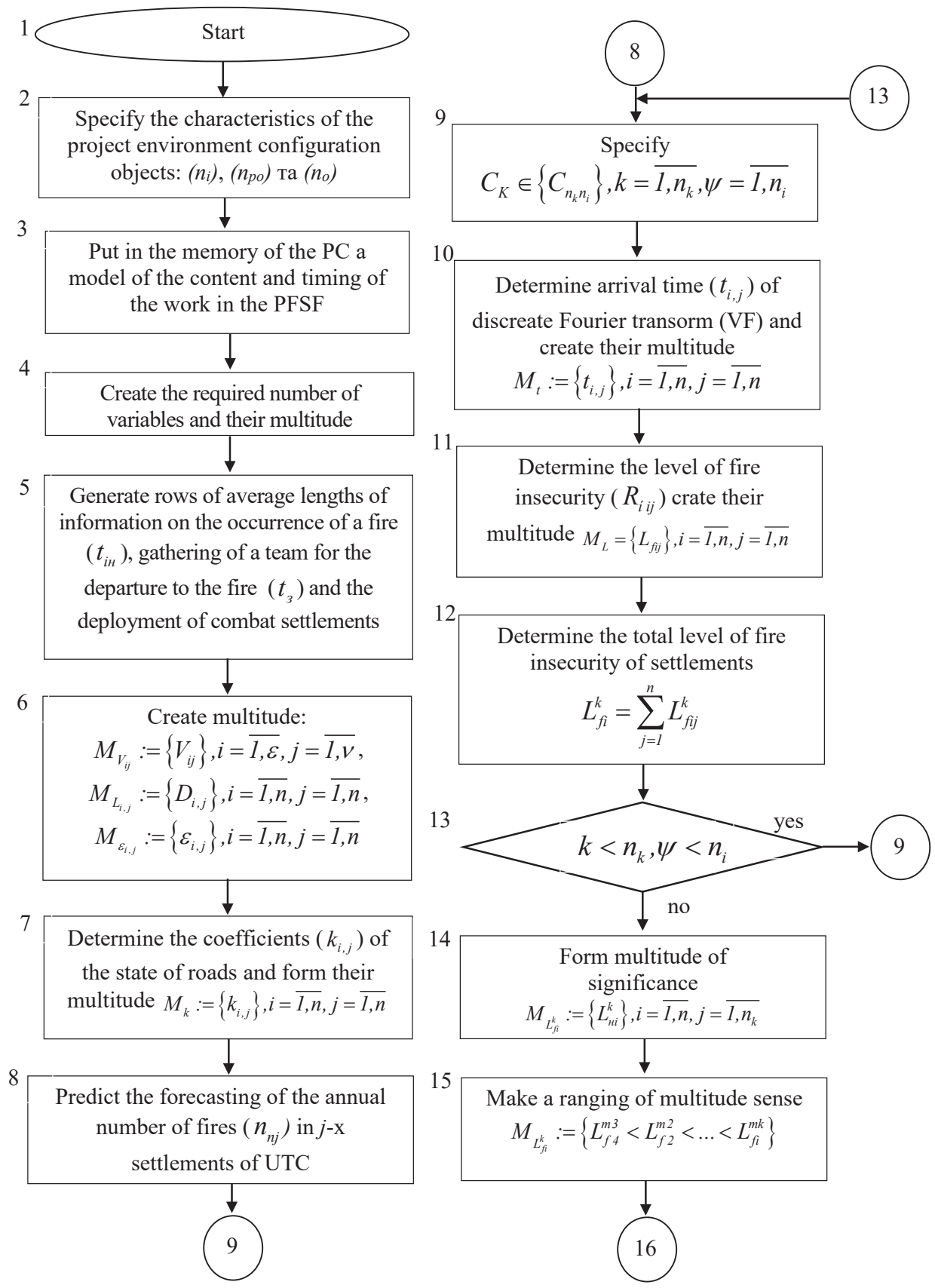

3a: Block diagram of the algorithm of the service model of PDSF (beginning)

14. To determine an effective configuration $\left(K_{S \sigma}^{e}\right)$ of local authorities fire extinguishing systems in the desired level due to the criteria $L_{f}^{m k} \rightarrow \min$ of minimal total populated areas fire insecurity level (19).

15. To specify the parameters of the configuration objects $\left(O_{K}\right)$ of local authorities fire extinguishing systems in the desired level: type and quantity of technical equipment; the number of executives of the fire brigade.

16. To carry out simulation of work performance in a project development of configuration objects according to predicted type and number of fires in j local authorities populated areas, specified parameters of the configuration objects $\left(O_{K}\right)$ of local authorities fire extinguishing systems in the desired level and design environment configuration.

17. To conduct calculation of organizational and technological indicators of value $\gamma$ in Project for the development of configuration objects.

18. To carry out the evaluation of the local authorities fire extinguishing system project value $O_{u}^{\prime}$.

19. To check the availability of pending configuration alternatives of local authorities 


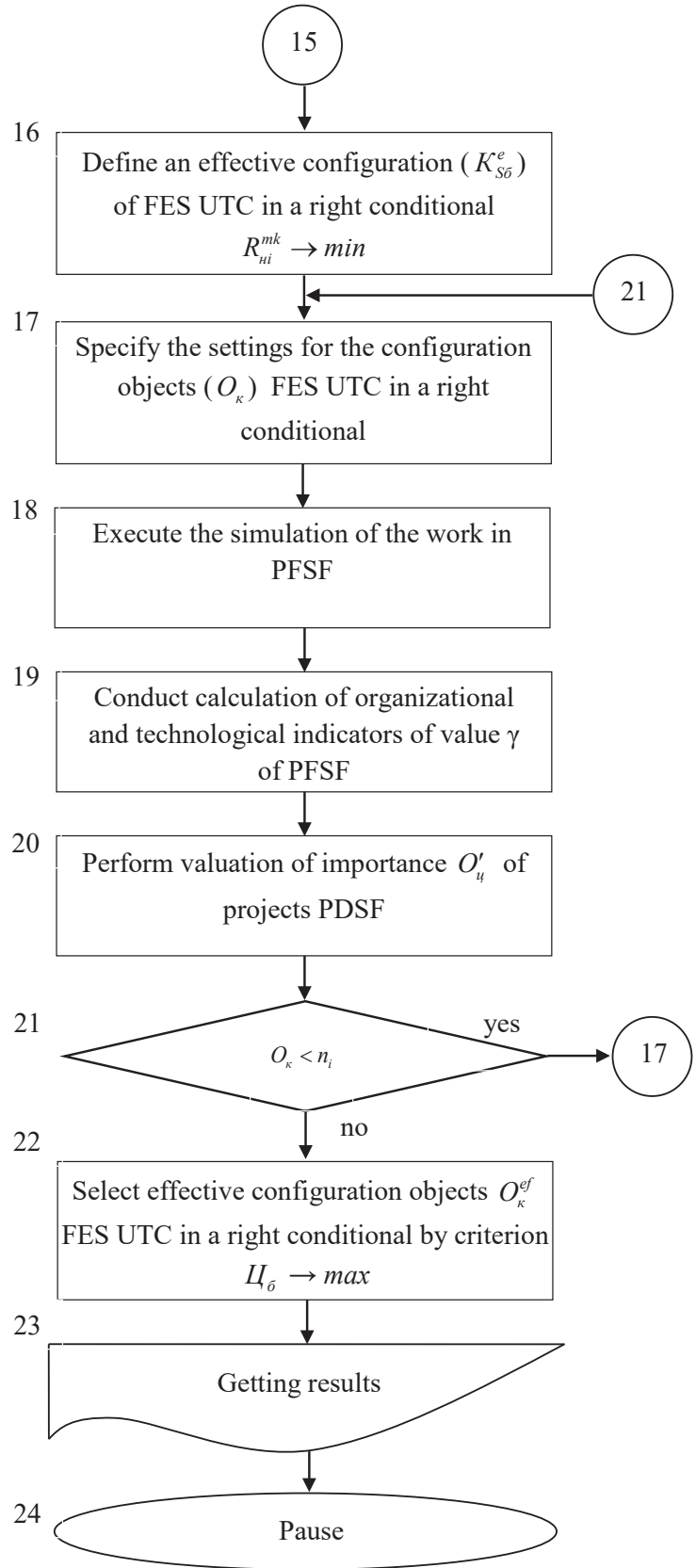

3b: Block-diagram of the algorithm of the service model PDSF (ended)

fire extinguishing systems in the desired level $\left(O_{K}\right)$ of local authorities fire extinguishing systems in the desired level and design environment configuration. In case of their availability go back to $\mathrm{p}$. 16. In case of their nonavailability - go to p. 20 .

20. To choose aneffective configuration objects of local authorities fire extinguishing systems in the desired level.

21. Fill in the received results in the array of results. Print out the results and shut down the project.

Based on the algorithm above, was developed a computer program on the Python 3.6 language.

\section{RESULTS AND DISCUSSION}

On the basis of simulation of local authorities fire extinguishing systems in the desired level in project development of configuration objects lays down the developed scientific methodological principles and the method of substantiation of their configuration in the desired level, as well as the results of identification of the objects of the said projects configuration and their design environment. Project development of configuration objects simulation was carried out for Zhovtantsi local authority conditions of Kamianka-Buzka districtin Lviv region.

To study the influence of the design environment characteristics, validated scenarios for the development of local authorities fire extinguishing systems, parameters of projects configuration objects on the organizational and technological values and cost indicators of their value, the project development of configuration objects simulation modeling was carried out. For this purpose, the service model of the local authorities fire extinguishing system project has been developed. The algorithm of this model is shown in Fig. 3. Based on this algorithm, a computer program in Python 3.6 was developed (Fig. 4).

In our studies, five variants of scenarios for the creation of the VF in the United Territorial Communities of Zhovtantsi are considered, and twelve variants of their geographical location (in each of the of the localities United Territorial Communities). On the basis of PFSF simulation in the desired conditions for United Territorial Communities of Zhovtantsy, their organizational and technological indicators are defined, namely: duration of individual works in the projects, the duration of the arrival of the VF to the place of fire, the total level of fire insecurity of the United Territorial Communities localities.

On the basis of the conducted researches, was established that for the project environment of the United Territorial Community of Zhovtantsy, the average duration of arrival of the VF to the place of fire is variable and depends on the type of fire formation, and on their territorial location (Fig. 5).

Based on the presented diagram (Fig. 5) it can be said that for all variants of the territorial location of the VF, the least value of the average duration of their arrival to the place of fire in the United Territorial Community of Zhovtantsy have scenarios of development of the fire extinguishing system, which provide for creation of the fire brigade of the I category, and the most - creation of fire brigades. Furthermore, concerning to the territorial location of the VF, the smallest average duration of their arrival at the place of fire is provided by variants that predict the location of fire brigades in the Zhovtantsy and Kolodentsy villages. In this case, the average duration of VF arrival to the place of fire, provided the location of fire brigades in the Zhovtantsy and Kolodentsy villages respectively are 15.72 and $15.52 \mathrm{~min}$. 


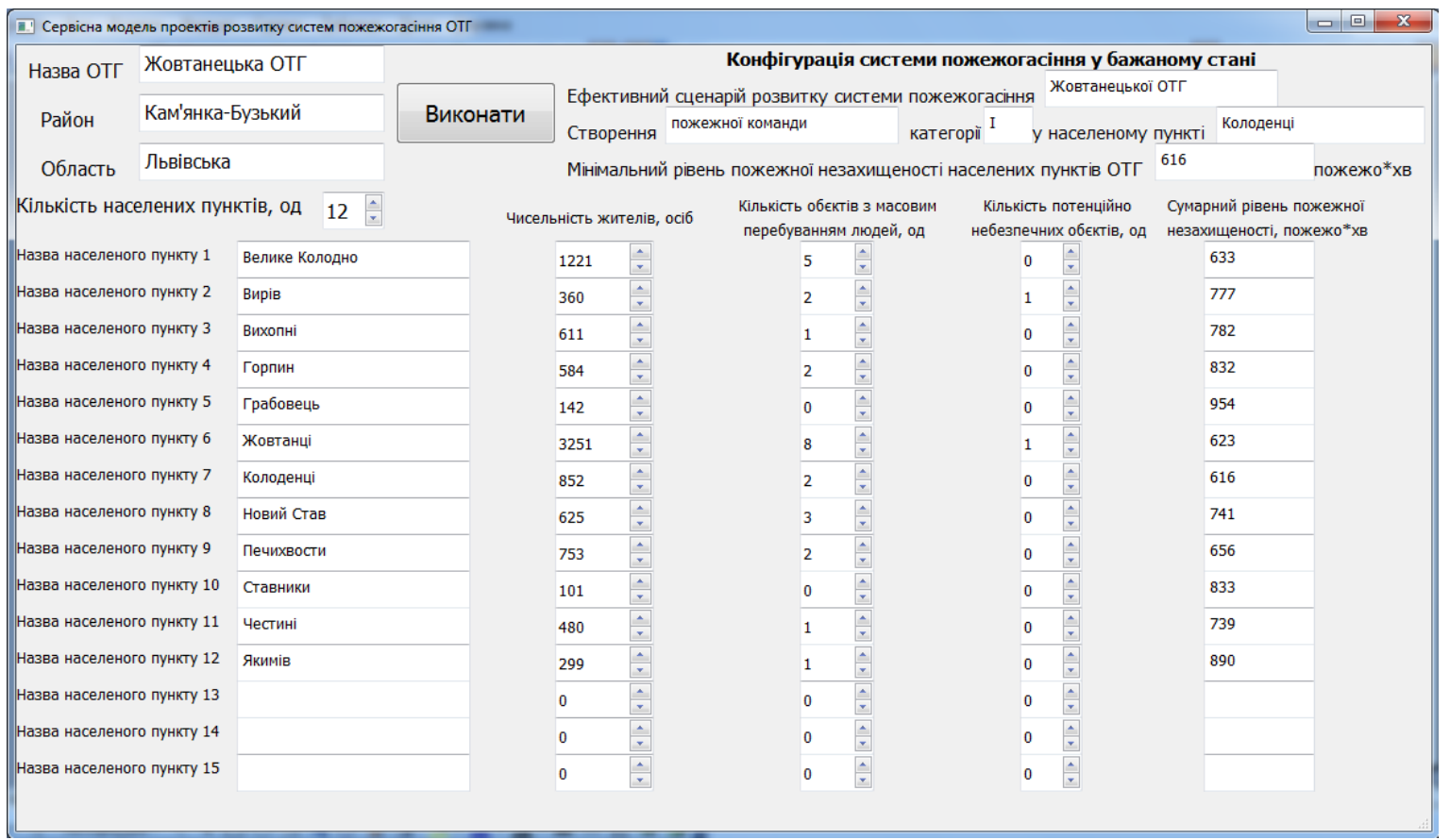

4: Window of the service model of local authorities fire extinguishingsystemproject (FFS UTC)

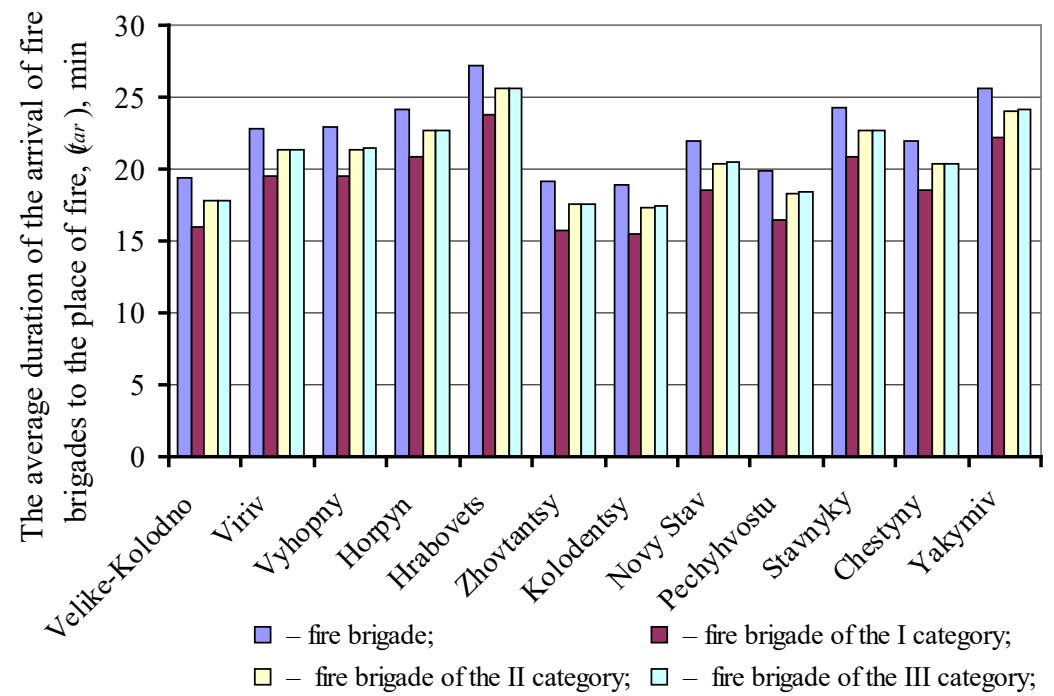

5: Diagram of change of average duration (tar) of the VF arrival to the place of fire in the territory of the United Territorial Community of Zhovtantsy, which depends on their type and territorial location

Based on the results of analysis of PFSF simulation for conditions of the United Territorial Communities of Zhovtantsiy in the desired state of the fire extinguishing system, it is constructed the dependence of the average duration (tap) of the arrival of certain species of VF to the place of fire from the population (про) in the places where is located VF (Fig. 6).

The dependence (Fig. 6) of the average duration (tar) of the certain types of VF arrival to the place of fire on the territory of the United Territorial Community of Zhovtantsy from the population (npo) in the locality where the fire brigade is located are described by the power equations:

- fire brigades

$$
t_{a r}=43.086 \times n_{p o}^{-0.106}, r=0.8
$$

- fire brigade of the I category

$t_{a r}=41.112 \times n_{p_{0}}^{-0.125}, r=0.82 ;$

- fire brigade of the II and III category

$t_{a r}=42.135 \times n_{p o}^{-0.113}, r=0.81$. 


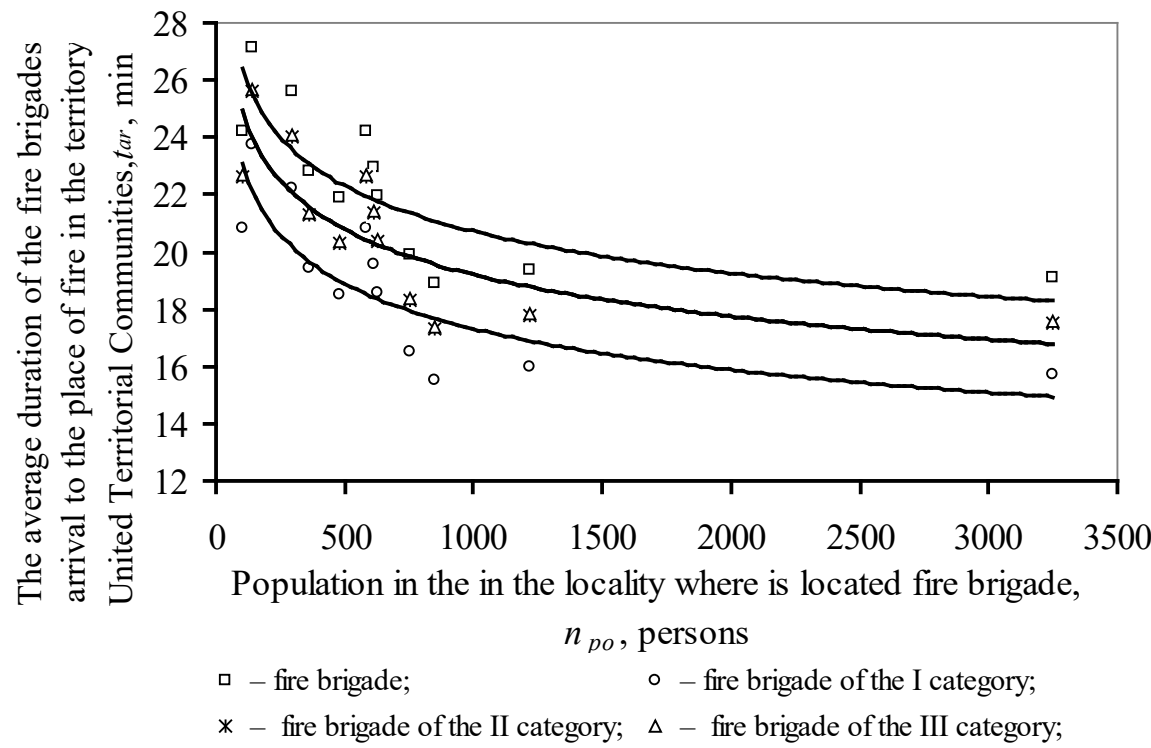

6: Dependence of the average duration (tar) of the certain types of United Territorial Communities arrival to the place of fire on the United Territorial Community of Zhovtantsy territory from the population (npo) in the locality where the fire brigade is located

In relation to the total level of fire insecurity $\left(L_{f}\right)$ of the United Territorial Community of Zhovtantsy localities, it is changeable and depends on the type of $\mathrm{VF}$ and its territorial location (Fig. 7)

The results, which we received concerning the quantitative values of the total level of fire insecurity $\left(L_{f}\right)$ of the United Territorial Community of Zhovtantsy localities are processed using the well-known method (Triguba et al., 2018), and the results are presented in Tab. I.

On the basis of the data from Tab. I it can be confirmed that the total level of fire insecurity $\left(L_{f}\right)$ of Zhovtanetska UTC is changeable. It is described by Weibull distribution laws for the creation of different types of VF. At the same time, provided the VF is established on the territory of Zhovtanetska UTC, the level of fire insecurity $\left(L_{f}\right)$ of its settlements varies within the limits of $578 \ldots 1161$ fires.min. The least mathematical expectation of the total fire insecurity level $\left(L_{f}\right)$ of settlements is observed on condition of a fire department's creation of category I and is $M\left[L_{f}\right]=764$ fires $\cdot \min$, which is by $18.5 \%$ lower than the variant of the fire brigades creation who have the largest value which is $M\left[L_{f}\right]=905$ fires $\cdot \mathrm{min}$.

On the basis of the results obtained regarding to the quantitative value of the total fire insecurity level $\left(L_{f}\right)$ of Zhovtanetska UTC settlements, a histogram of its change was generated for the creation of VF of different types (Fig. 8).

On the basis of presented on Fig. 8 diagrams, it can be confirmed that the difference between the average and the minimum and maximum and average values of the total fire insecurity level $\left(L_{f}\right)$ of Zhovtanetska UTC settlements is almost the same for the creation of all VF types and, accordingly, the moderately deviation ranges from 100.8 to 104.6 fires:min.
Obtained, on the basis of modeling, quantitative values of organizational and technological indexes of the PFSF (project of functioning of the fire extinguishing system of the united territorial community) in the desired state of the FES UTC made it possible to construct the dependence of the total fire insecurity level $\left(L_{f}\right)$ of settlements on the average duration $\left(t_{a r}\right)$ of certain VF types arrival to the fire location on the territory of Zhovtanetska UTC (Fig. 9).

Indecated dependence is described by the linear equation:

$L_{f i}=41.011 t_{a r}-20.678, r=0.99$.

Dependence (Fig. 9) indicates that with the increase of the average duration (tar) of the certain fire units' types arrival to the place of fire on the UTC territory, the total level of settlements' fire insecurity $\left(L_{f}\right)$ increases proportionally. In the obtained dependence, the correlation ratio is 0.99 , which indicates a strong connection between the total level of settlements' fire insecurity $\left(L_{f}\right)$ and the average duration (tar) of certain DPF types arrival to the fire location on the territory of the UTC.

It is known that the duration $\left(t_{a r}\right)$ of the VF arrival to the fire location on the territory of the UTC is regulated and it should not exceed 20 minutes. It corresponds to the total level of its settlements' fire insecurity $\left(L_{f}\right)$, which is $L_{f}=800$ fires $\cdot \mathrm{min}$. Consequently, due to presented dependence (Fig. 9), we can say that most of the considered options for setting up an FES do not meet this requirement. They do not provide fire protection for settlements on the territory of Zhovtanetska UTC and should not be considered during substantiating the effective configuration of the FES UTC in the desired state. 

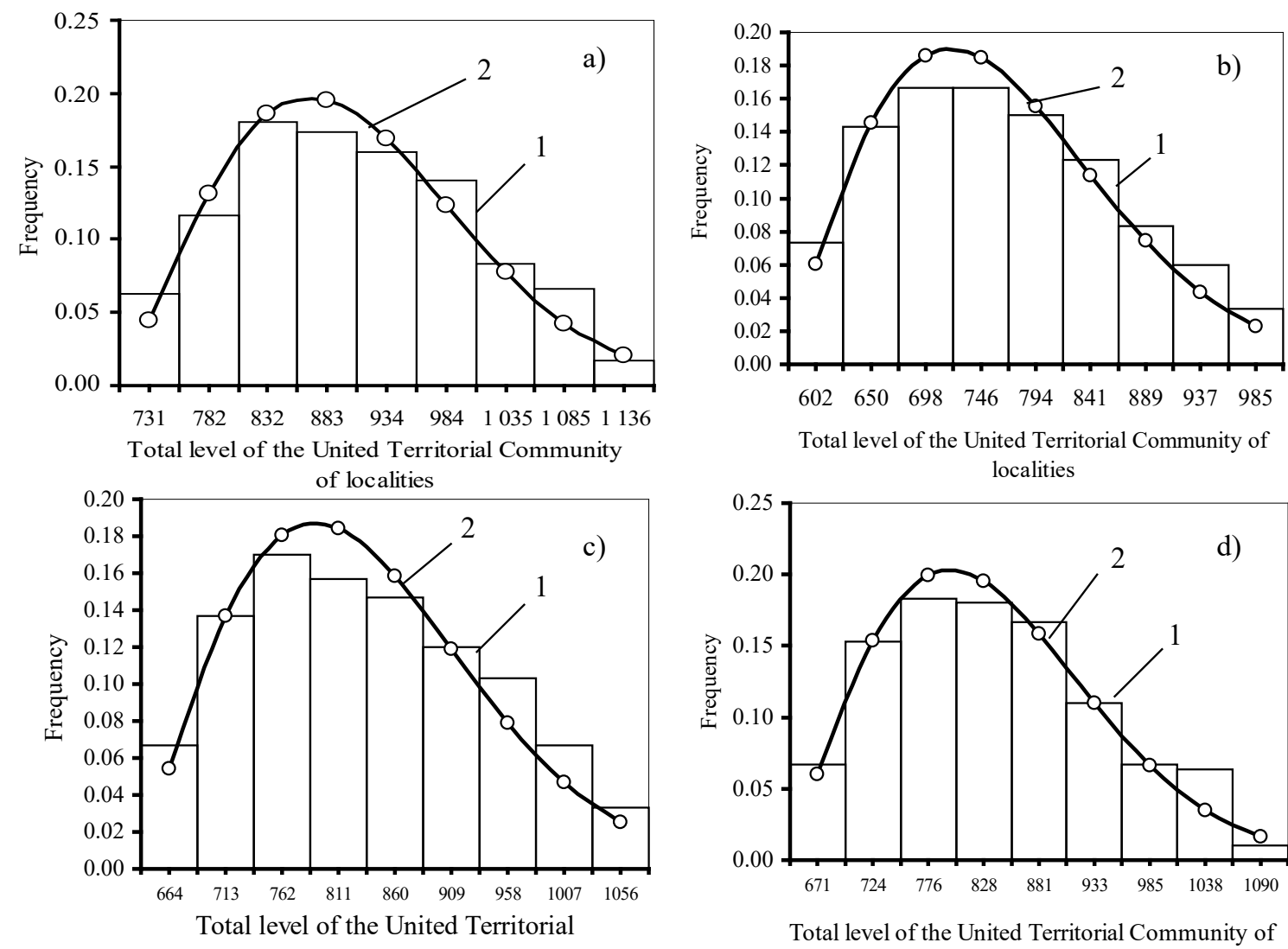

Total level of the United Territorial Community of localities

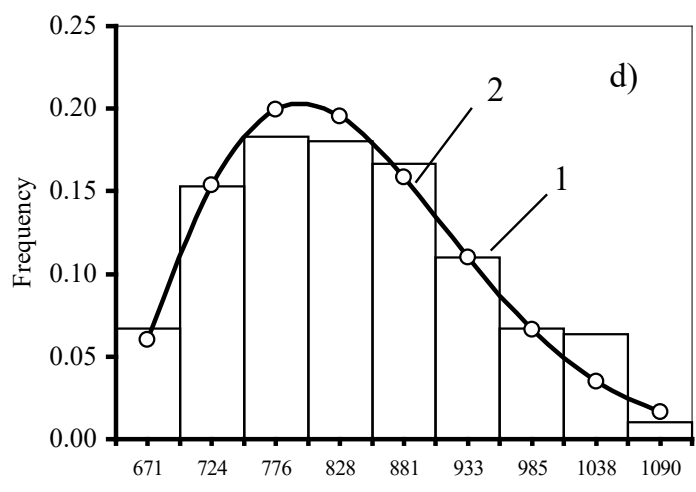

Total level of the United Territorial Community of localities

7: The histogram (1) and the theoretical curve (2) of the total level distribution of fire insecurity ( $L_{f}$ ) of the United Territorial Community of localities provided creation of the fire brigades (a), fire brigades I (a), II (б) and III (в) categories.

I: Determination results of the total level of fire nsecurity $\left(L_{f}\right)$ of the United Territorial Community localities, fire.min.

\begin{tabular}{|c|c|c|c|c|c|c|c|}
\hline \multirow{2}{*}{$\begin{array}{c}\text { Organization variant of the fire insecurity creation } \\
\text { of the United Territorial Community }\end{array}$} & \multicolumn{2}{|c|}{ Meaning } & \multirow{2}{*}{$\mathrm{X}^{2}$} & \multicolumn{4}{|c|}{ Statistical characteristics } \\
\hline & $\min$ & $\max$ & & $\mathrm{M}\left[\mathrm{L}_{\mathrm{fi}}\right]$ & $\mathrm{D}\left[\mathrm{L}_{\mathrm{fi}}\right]$ & $\mathrm{G}\left[\mathrm{L}_{\mathrm{fi}}\right]$ & $\mathrm{v}\left[\mathrm{L}_{\mathrm{fi}}\right]$ \\
\hline Fire brigades & 706 & 1161 & 8.7 & 905 & 10170 & 100.8 & 0.5 \\
\hline Fire brigades of the I categories & 578 & 1009 & 5.9 & 764 & 10187 & 100.9 & 0.54 \\
\hline Fire brigades of the II categories & 639 & 1081 & 8.1 & 835 & 10941 & 104.6 & 0.53 \\
\hline Fire brigades of the III categories & 645 & 1116 & 8.6 & 839 & 10480 & 102.3 & 0.52 \\
\hline
\end{tabular}

$M\left[L_{f}\right], D\left[L_{f}\right], G\left[L_{f}\right], v\left[L_{f}\right]$ - respectively, mathematical expectation, variance, mean square deviation and coefficient of variation of the total level of fire insecurity of localities

Consequently, the main organizational and technological value indexes of the PDSF in the desired state depend on the type of configuration objects and the territorial location of the DPF on the territory of the UTC. The substantiated quantitative values of the corresponding organizational and technological value indexes and the tendencies of their changes are the basis of the definition of cost indexes and conducting of optimization calculations in relation to substantiation of the effective FES UTC configuration in the desired state.

\section{CONCLUSION}

Analysis of the situation of firefighting systems and project management of their development made it possible to establish that they do not work effectively in Ukraine's rural areas, which necessitates their reengineering due to the implementation of the relevant projects.

The EU countries and the USA experience regarding the operation of fire extinguishing systems in rural areas testifies to the expediency of the creation of voluntary fire brigades on the territory of the united territorial communities of Ukraine through the implementation of relevant projects. 


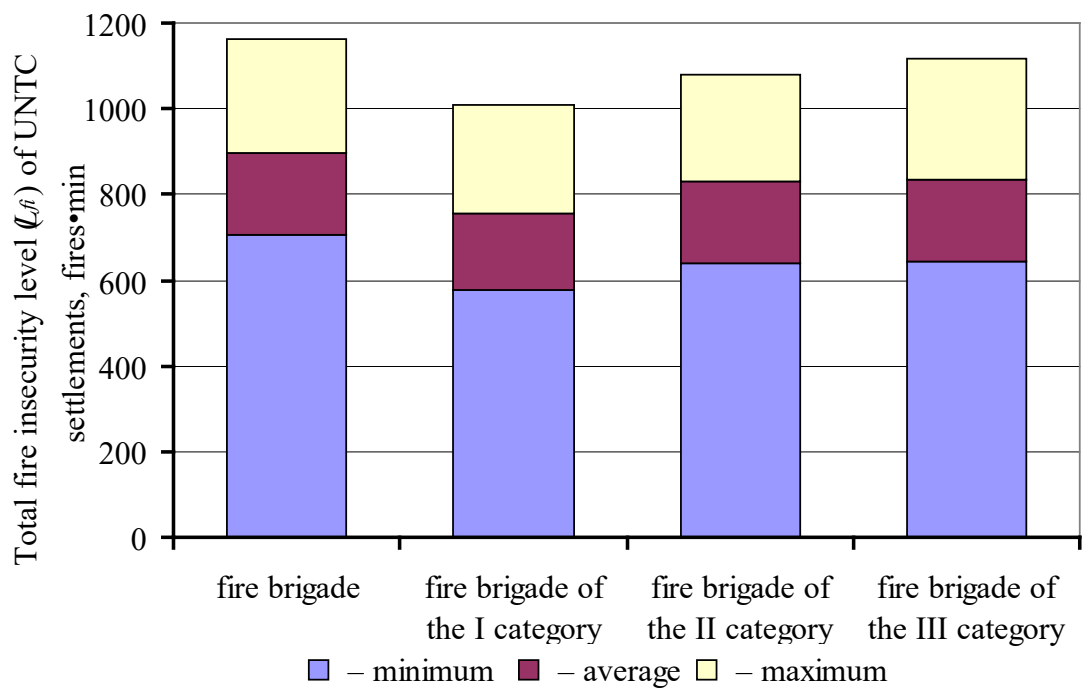

8: Tendencies of change of the total fire insecurity level $\left(L_{f i}\right)$ of Zhovtanetska UTC settlements

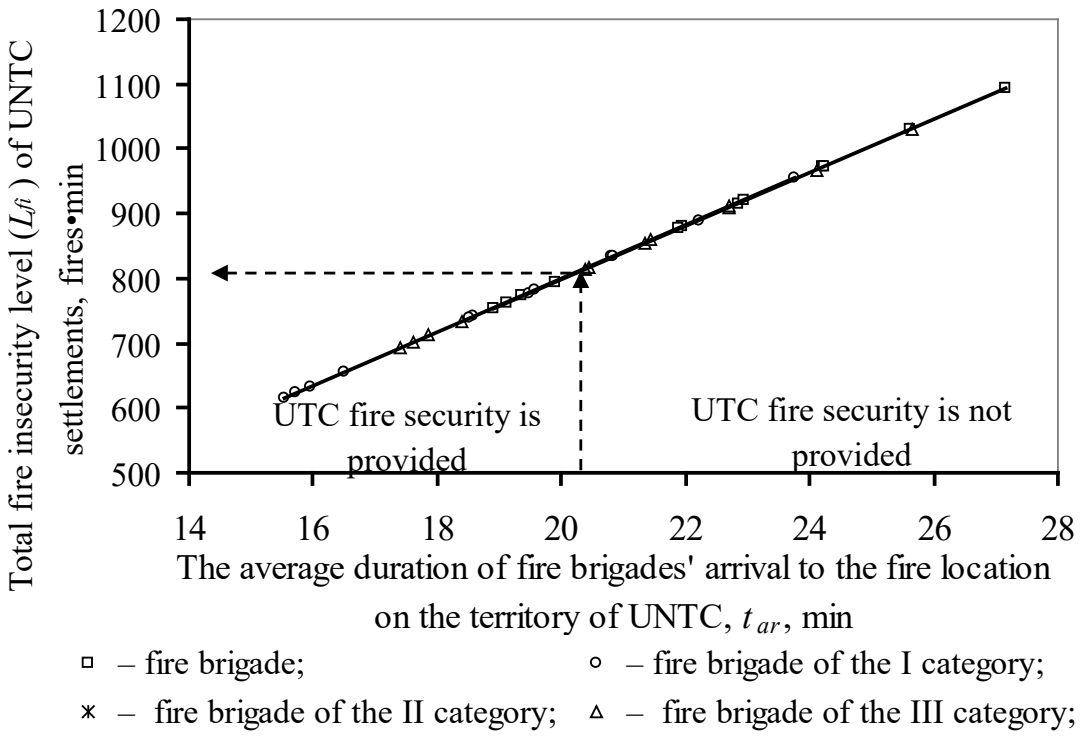

9: Dependence of the total fire insecurity level $\left(L_{f}\right)$ of settlements on the average duration $\left(t_{a r}\right)$ of certain VF types' arrival to the fire location on the territory of Zhovtanetska UTC

For the implementation of projects for the development of united territorial communities fire extinguishing systems, scientific and methodological principles and service model should be developed, it will take into account both the features of the development projects of fire extinguishing of the combined territorial communities and the specifics of their changing project environment. The scientific and methodological principles of the justification of the configuration of the fire extinguishing system of the combined territorial communities in the desired state are based on the conceptual and simulation models of the desired fire extinguishing system of the combined territorial communities and provides determination of the effective type of the fire depot and its optimal location on the territory of the community according to the complex criterion fire insecurity of human settlements taking into account the changing configuration of the project environment (number of inhabitants in settlements, presence of fire hazard objects and characteristics of the road network in the territory united local communities).

The developed service model of FES UTC is based on an algorithm that involves the implementation of 23 steps, which provides simulation modeling of PFSF projects and provides a quicker justification of the configuration of the fire extinguishing system of the combined territorial communities in the desired state. It made it possible to carry out a study of the influence of the characteristics of the project environment, substantiated variants of scenarios for the development of the fire extinguishing 
system of the combined territorial communities and the parameters of the objects of configuration of their projects on organizational and technological and cost parameters valuations.

It has been established that the main organizational and technological indicators of the value of FES UTC depend on both the type of configuration objects and the territorial location of the VF in their territory. It is substantiated that the total level of fire insecurity of the settlements of the Zhovtanets United Territorial Community is variable and for separate scenarios of the development of fire extinguishing systems it is described by its law of Weibull distribution, and its quantitative data in case of the establishment of fire brigades varies between - 706 ... 1161 fires min, fire brigades of I, II and III categories respectively - 578 ... 1009, $639 \ldots 1081$ and 645 ... 1116 fires.min.

Further research should be made regarding the valuation of FES UTC. This will enable to develop a conceptual plan for managing these projects on the pre-investment (conceptual) phase of its implementation, which involves the consistent implementation of seven interrelated processes for managing the project, which provides justification for the set of transformations, actions and resource requirements with the possibility of obtaining maximum value.

\section{Acknowledgements}

The presented work was performed in accordance with the research development "Development of project-led innovative systems, resource-saving technologies and technical means in agroindustrial production and its security” (state registration number: 0108 U 006940). Funded by Ministry of Education and Science of Ukraine.

\section{REFERENCES}

BAIGENT, D. 2001. One more working class hero: A cultural audit of the UK Fire Service. Cambridge, United Kingdom. Fire Research and Training Unit, 12(36): 101-109.

CLANCY, D. and HOLGATE, A. 2004. Rural fire fighters' experience of risk on the fireground. In: $39^{\text {th }}$ Annual Conference of the Australian Psychological Society. Sydney, Australia.

FERREIRA, T., VICENTE, R., COSTA, A. et al. 2016. Urban fire risk: Evaluation and emergency planning. Journal Of Cultural Heritage, 20(C): 739-745.

GWYNNE, S., GALEA, E. R., PARKE, J. et al. 2003. The collection and analysis of pre-evacuation times derived from evacuation trials and their application to evacuation modeling. Fire Technology, 39(2): 173-195.

HULIDA, E., PASNAK, I., KOVAL, O. et al. 2019. Determination of the Critical Time of Fire in the Building and Ensure Successful Evacuation of People. Periodica Polytechnica Civil Engineering, 63(1): 308316.

KOPEČKOVÁ, M. and MÁCHAL, P. 2016. Survey on the Level of Knowledge and Skills of Project Managers in Regional Development. Acta Universitatis Agriculturae et Silviculturae Mendelianae Brunensis, 65(4): 1205-1212.

KOPEČKOVÁ, M. and MÁCHAL, P. 2016. Survey on the Level of Knowledge and Skills of Project Managers in Regional Development. Acta Universitatis Agriculturae et Silviculturae Mendelianae Brunensis, 64(4): 1325-1335.

KOVALCHUK, V. 2015. Voluntary fire organizations in the foreign countries systems of civil protection in the context of public authorities tasks in the national security field. Efficiency of public administration: Collection of scientific works, 44: 132-139.

LOVREGLIO, R., RONCHI, E. and NILSSON, D. 2015. A model of the decision-making process during pre-evacuation. Fire Safety Journal, 78: 168-179.

MACHADO TAVARES, R., GWYNNE, S. and GALEA, E. R. 2007. Collection and analysis of pre-evacuation time data collected from evacuation trials conducted in Library Facilities in Brazil. Journal of Applied Fire Science, 15(1): 23-40.

MÁCHAL, P. 2009. Possibilities of application of process modelling when developing a proposal of the business process management system for a university department. Acta Universitatis Agriculturae et Silviculturae Mendelianae Brunensis, 57(2): 61-68.

MARRION, C. 2016. More effectively addressing fire/disaster challenges to protect our cultural heritage'. Journal of Cultural Heritage, 20(C): 746-749.

MCLENNAN, J. and BIRCH, A. 2008. Why would you do it? Age and motivation to become a fire service volunteer. The Australian and New Zealand Journal of Organisational Psychology, 1(1): 7-11.

RATUSHNYI, R., KHMEL, P., TRYHUBA, A. et al. 2019. Substantiating the effectiveness of projects for the construction of dual systems of fire suppression. Eastern-European Journal of Enterprise Technologies: Control processes, 3(100): 46-53. 
SABOLOVIČ, M. 2011. An alternative methodological approach to value analysis of regions, municipal corporations and clusters. Acta Universitatis Agriculturae et Silviculturae Mendelianae Brunensis, 59(3): 91-100.

TRIGUBA, A., BOYARCHUK, O., RATUSHNY, R. et al. 2018. Criteria for projects and programs for the administrative territories development evaluation. In: Modern trends of training specialists in project and program management. Materials of sc. - pr. Conf, pp. 105-109.

TRUSH, O. 2009. Experience of the Western Europe European Union member countries civil protection systems construction and functioning. The theory and practice of public administration, 4(27): 441-447.

TRYHUBA, A., PAVLIKHA, N., RUDYNETS, M. et al. 2019. Substantiating the effectiveness of projects for the construction of dual systems of fire suppression. Eastern-European Journal of Enterprise Technologies: Control processes, 3(99): 50-63.

TRYHUBA, A., RATUSHNY, R., BASHYNSKY, O. et al. 2018. Identification of firefighting system configuration of rural settlements. In: Fire and Environmental Safety Engineering. MATEC Web Conf. 247 (FESE 2018).

TRYGUBA, A., RATUSHNY, R., SHCHERBACHENKO, O. 2018. Scientific and methodological grounds for investigating the connections in fire extinguishing systems of the united territorial communities. Przedsiębiorczość i zarzadzanie: Bezpieczeństwo zintegrowane wspótczesnej Polski, 2(3): 153-166.

TRYGUBA, A., RATUSHNY, R., SHCHERBACHENKO, O. et al. 2018. System approach to the investigation of the projects of the fire-fighting systems' functioning and development of the united territorial communities. TEKA an international quarterly journal on motorization, vehicle operation, energy efficiency and mechanical engineering, 18(5): 49-53.

TRYHUBA, A., ZACHKO, O., GRABOVETS, V. et al. 2018. Examining the effect of production conditions at territorial logistic systems of milk harvesting on the parameters of a fleet of specialized road tanks. Eastern-European Journal of Enterprise Technologies: Control processes, 5/3(95): 59-70.

XIN, J. and HUANG, C. 2013. Fire risk analysis of residential buildings based on scenario clusters and its application infire risk management. Fire Safety Journal, 62: 72-78.

Contact information

Anatoliy Tryhuba: trianamik@gmail.com

Roman Ratushny: ratushnyi@ldubgd.edu.ua

Inna Tryhuba: trinle@ukr.net

Nazar Koval: kovaln@ldubgd.edu.ua

Igor Androshchuk: AndroschukIgor@lutsk-ntu.com.ua 
